\title{
The Role of Interreligious Dialogue in Addressing Ideological Support for Terrorism: Roman Catholic Perspectives
}

\author{
Albert A. Agresti, S.J. *
}

The roots of the Roman Catholic Church's efforts in interreligious dialogue over the past half-century rest in the work of a number of individuals, including that of the American Jesuit John Courtney Murray. Fr. Murray was among several whose views and writings on this question during the first half of the twentieth century were viewed with suspicion in some Roman Catholic circles, as they evidenced too much influence from democratic ideals and principles that were, in some cases, at odds with official Church teaching. ${ }^{1}$ Yet, during the Second Vatican Council (or Vatican II) held between 1963 and 1965, he and others saw their once suspect opinions incorporated into official Church teaching. This is an excellent example of how culture and belief often interact to bring about something new, something positive-an example of how patient perseverance, coupled with hope, can help bring about change.

While major developments in interreligious dialogue have occurred over the past century, this is not to suggest that interactions between Roman Catholicism and nonChristian religions, and especially Islam, can only be traced to this period. It goes without saying that the West is highly indebted to many great Islamic thinkers such as Averroes (Ibn Rushd) and Avicenna (Ibn Sina) — to name only two-for their influence on and contributions to the world's knowledge in such areas as medicine, philosophy, and mathematics. Indeed, the philosophical and theological writings of St. Thomas Aquinas, one of the greatest Roman Catholic thinkers, were deeply influenced by Islamic thought.

When it came to an actual conversation or dialogue around specifically theological and religious issues, however, before the Second Vatican Council the dominant view within the Catholic tradition was that, while other religious traditions may have some element of truth to them, they were fundamentally erroneous. Consistent with this position, any notion of interreligious dialogue (not to mention religious freedom) on the part of the Catholic Church was a logical inconstancy. This view helped fuel intense missionary efforts to convert others to the Catholic faith, since all other faiths were thought to be untrue. In fairness, Roman Catholicism was not alone in this view. Although it might be articulated differently in other traditions, its effects are equally discernable. For example, the spread of Christianity, specifically Anglicanism, went hand-

\footnotetext{
Albert A. Agresti, S.J., has served as a professor of psychology at several Jesuit universities in the U.S. He is currently the Director of the Campion Renewal Center in Weston, MA.

1 Fr. Murray's writings in this area are extensive. His collection of essays published in his book, We Hold These Truths, offers an excellent overview of his thought. See Murray, We Hold These Truths: Catholic Reflections on the American Proposition (New York: Sheed \& Ward, 1960).
} 
in-hand with the spread of the British Empire. Today the extensive Anglican Communion is composed of many peoples who were once a part of that far-flung empire.

Vatican II issued three documents dealing explicitly with religious pluralism. ${ }^{2}$ One of these documents was the "Decree on Ecumenicism" (Unitatis Redintegrato, or "Restoration of Unity"). As the title suggests, this document addresses the relationship of the Roman Church with other Christian traditions. The remaining two documents are important and directly relevant to our topic. The first deals with the Church's relationship with non-Christian religions, and the second deals with religious freedom. Indeed, these two documents may well be the most controversial of the sixteen official pronouncements issued by the Council. There were numerous arguments raised-some reasonable and others less so-for holding them in committee, watering them down, and even keeping them off the Council's agenda (not to mention the Council floor) for discussion. It was only due to the astute diplomatic efforts of the respected Jesuit scripture scholar, Cardinal Augustin Bea, and the implicit confidence that both Pope John XXIII and Pope Paul VI had in Cardinal Bea that these documents saw the light of day. ${ }^{3}$

The first document is the "Declaration on the Relationship of the Church to NonChristian Religions" (Nostra Aetate, or "In our Times"). In this document, we see a profound paradigmatic shift in the Church's view of and approach to non-Christian religions. The Catholic Church committed itself to seeking commonalities among differing religious beliefs, recognizing that all religious traditions have much to offer, and acknowledging that the Church is called to an openness to the insights that other faiths contain: "In [the Church's] task of fostering unity and love among men, and even among nations, she gives primary consideration in this document to what human beings have in common and to what promotes fellowship among them." ${ }^{4}$ While clearly acknowledging that one should not attempt to deny or neglect differences, for to do so would be to engage in an inauthentic conversation, prime focus and attention is to be given to things that are common among religions and that have the potential to unite rather than divide. "Other religions to be found everywhere strive variously to answer the restless questions of the human heart.... The Catholic Church rejects nothing which is true and holy in these religions. She looks with sincere respect upon those teachings of conduct and life, those rules and teachings which, though differing in many particulars from what she holds and sets forth, nevertheless often reflect a ray of that Truth which enlightens all men."5

This document established the context for genuine conversation between faiths within the Catholic Church, a sincere dialogue grounded in mutual respect of another's religious beliefs and fidelity to one's own. A specific invitation and expressed desire

2 Walter Abbott, S.J., The Documents of Vatican II (New York: The America Press, 1966). ious Dialogue and Relations (October 2005). Available at: http://puffin.creighton.edu/jesuit/ dialogue/documents/articles/njn_borelli_02.html.

5 Ibid., 662. 
for reconciliation was extended to those of the Muslim faith to whom the Church "looks with esteem." The document stated, "Although in the course of the centuries many quarrels and hostilities have arisen between Christians and Moslems, this most sacred Synod urges all to forget the past and to strive sincerely for mutual understanding. On behalf of all mankind, let them make common cause of safeguarding and fostering social justice, moral values, peace, and freedom."7

While differences do exist between Catholics and Muslims, there is much on which we agree, and much we can do together to help us achieve our common desires and goals. Interreligious dialogue was close to the hearts of both John XXIII (who had served as a diplomat in Istanbul) and Paul VI. In 1964, a year before the conclusion of the Second Vatican Council, while the draft of Nostra Aetate was still under consideration and had yet to be approved and promulgated by the Council, Paul VI established a special department in the Roman Curia for relations with people from other faiths. It was first called the Secretariat for Non-Christians, and was later renamed the Pontifical Council for Interreligious Dialogue. In August 1964, Paul VI issued his first encyclical, Ecclesiam Suam ("Paths of the Church"), in which he clearly outlined the importance of interreligious dialogue. It is reasonable to assume that Paul VI's decision to issue this encyclical while the draft of Nostra Aetate was still under consideration by the Council would leave little doubt in anyone's mind as to where he stood on the question.

The second document that is relevant to our topic is the "Declaration on Religious Freedom: On the Right of the Person and of Communities to Social and Civil Freedom in Matters Religious" (Dignitatis Humanae, or "The Dignity of the Human Person”). In this document, the Council explicitly acknowledged and gave positive interpretation to those elements of democratic principles that positively affect our growing awareness of the value and dignity of the human person, as well as the sacredness of a person's conscience and his or her relationship with God. The opening sentence of Chapter One, Section Two boldly asserts: "This Vatican Council declares that the human person has a right to religious freedom." ${ }^{\prime 8}$ For many of the bishops at the Council, this statement was, for all intents and purposes, a major shift in their world view. In order to explain this phenomenon, the document offers that, "in taking up the matter of religious freedom, this sacred Synod intends to develop the doctrine of recent Popes on the inviolable rights of the human person and on the constitutional order of society."

What the Council acknowledged was a simple fact. While the ultimate truth that all faiths seek may not change, human efforts to understand and articulate it are always incomplete, and so are in need of review and, at times, further development. The bishops of the Catholic Church embraced the principle that the Church's teaching not only can evolve, but that at certain moments-prompted by and under the guidance of the Holy

6 Ibid., 663.

Ibid.

8 Ibid., 678.

9 Ibid., 677. 
Spirit-it must evolve in order to remain responsive to humanity. ${ }^{10}$ In this reference to the "constitutional order of society," the Council embraced and carried forth John XXIII's assertion in his encyclical Pacem in Terris ("Peace on Earth") — the first papal encyclical addressed to the entire world and not just to members of the Roman Catholic Church — that the dignity of the human person requires that there must be constitutional limits to the powers of government.

The Church no longer viewed democratic principles with suspicion, but recognized the need to be both willing and able to engage in dialogue with what was clearly a significant movement in human history. Given the context in which this document was written-during the Cold War, and in the wake of World War II - there was an implicit recognition of the need to safeguard the individual within a totalitarian state. The Church, however, did not limit her concern to these states. The Council explicitly asserted the belief in the need to safeguard the individual vis-à-vis all forms of government. The premise for this is the dignity of the human person, created in the image and likeness of God.

For those interested in interreligious dialogue as a way of countering ideological support for terrorism, this dialogue must be a true and honest one. We must be ready and willing to ask ourselves, as well as our governments, our respective news media, and other information providers and image-makers a number of questions:

- What do we need in order to enable us to be receptive to hearing what others may have to say to us, how they may desire to touch our hearts and minds?

- Are we willing and able to point out these needs and insist that, when necessary, we rethink and change how we speak about those whom we wish to engage in dialogue, how they are depicted in the media, and how we choose the actions that will be the focus of our attention?

- Are we willing to hear what the other has to say with respect, to focus on what is common to us and what will help us all?

- Are we willing to enter into this conversation/dialogue ready to accept what is true in what others may want us to see? Or will we insist that this conversation, if it happens at all, be limited to all-too-predictable rhetoric and posturing?

We deceive ourselves if we think that this can be a unidirectional enterprise, that it is only the hearts and minds of others that need to be changed in an effort to counter ideological support for terrorism, that there is no need for change in our own hearts and minds. In a speech at the Oxford University's Centre for Islamic Studies in May 2006, Cardinal Cormac Murphy-O’Connor, the Archbishop of Westminster, noted that "dialogue will be impossible as long as minds are closed, as long as adherents of either

${ }^{10}$ Although certain Catholic teachings had evolved and developed over time, the Council explicitly and formally acknowledged this reality. See Thomas Noonan's A Church that Can and Cannot Change: The Development of Catholic Moral Teaching (Notre Dame, IN: University of Notre Dame Press, 2005) for an interesting analysis of the development of the Church's teaching in a number of areas, e.g. slavery. 
faith believe that we have nothing to learn from the other, or that the Spirit of God is not active in the whole of God's creation." ${ }^{11}$ The following month, Archbishop Jozef Wesolowski, head of the Holy See's delegation to a meeting of the Organization for Security and Cooperation in Europe, cautioned that, "if interreligious and intercultural dialogue is to succeed in helping to counter prejudices in civic and political life, then the educational system and the media must avoid stereotypes, distortions, attitudes of intolerance and the frequent belittling of religion and culture." ${ }^{\text {,2 }}$

There must be recognition that Islam, like Christianity and Judaism, is not a monolithic entity. Simplistic representations of "us" and "them" are misleading and essentially harmful. As Islam spread beyond Arab lands and peoples to the Indian subcontinent, Asia and the islands of the Pacific, sub-Saharan Africa, and elsewhere, it encountered new cultures and diverse political and economic systems and began to take on subtle but important nuances. The advance of Islam, like that of Christianity, is consistent with the belief that Islam, like Christianity, is a universal religion. This common belief in their universality provides both religions with their strong missionary self-understanding, and the consequent desire to convert others. In his speech cited earlier, Cardinal Murphy-O’Connor pointed out that “our two faiths are boldly universal. This is what we have in common and that has been the source, sometimes, of our tension. But universality is what makes our dialogue imperative."13

While we know all too well that violence has been employed in the past in missionary efforts, we must be unequivocal in our opposition to any attempts to impose one's religious beliefs on another, most especially when such attempts include the use of violence. In a joint statement issued by the Committee for Dialogue of the Pontifical Council for Interreligious Dialogue and the Permanent Committee of Al-Azhar for Dialogue with the Monotheistic Religions in February 2002, participants agreed that "extremism, from whatever side it may come, is to be condemned as not being in conformity with the teachings of the two religions." 14 At the conclusion of their meeting the following year, participants issued a statement asserting that "the sacred texts in both religions must be understood in their proper context. Isolating passages from their context and using them to legitimize violence is contrary to the spirit of our religions." 15

11 Cormac Murphy-O’Connor, “Catholic-Muslim Dialogue Today,” speech at the Centre for Islamic Studies, Oxford University (17 May 2006). Available at: www.indcatholicnews.com/ chmus239.html.

12 Jozef Wesolowski, “The Frequent Belittling of Religion and Culture,” remarks to a meeting of the Organization for Security and Cooperation in Europe in Almaty, Kazakhstan (13 June 2006). Available at: www.zenit.org/english/visualizza.phtml?sid=90883. Murphy-O’Connor, “Catholic-Muslim Dialogue.”

14 Vatican Press Office, "Interreligious Statement on Extremism," Vatican City (27 February 2002). Available at: www.zenit.org/english/war/visualizza.phtml?sid=17254.

15 Vatican Press Office, “Islamic-Catholic Statement on Terrorism and Peace,” Vatican City (2 March 2003). Available at: www.zenit.org/english/visualizza.phtml?sid=32142. 
In an address given in Geneva in April 2004 at the $60^{\text {th }}$ session of the United Nations' Human Rights Commission, Archbishop Silvano Tomasi, the Holy See's Permanent Observer to the UN's offices in Geneva, offered that, “All religions can make a unique contribution to a peaceful living together by rejecting the violent plans and means of some of their members who cover their destructive goals under the guise of religion and by opening instead the way for interreligious dialogue." ${ }^{\prime 6}$ In his address to the United Nations General Assembly in October 2004, Archbishop Celestino Miglore, the Holy See's Permanent Observer to the United Nations, stated that "religious leaders have a special responsibility in dispelling any misuse or misrepresentation of religious beliefs and freedom. They have in their hands a powerful and enduring resource in the fight against terrorism."17

Some who read or hear these words will scoff, thinking that religion has no positive role to play in attempts to counter ideological support for terrorism. At best, such observers may feel, religion is all well and good, but it is an essentially personal or private matter, and certainly has no appropriate-let alone potentially significant—role to play in international politics. At worst, religion is one of the main reasons the world is in the mess it is today. In her recent book, The Mighty \& the Almighty: Reflections on America, God and World Affairs, former U.S. Secretary of State Madeleine Albright takes issue with these traditional views, and outlines cogent reasons for her position that religion has already shown itself to be not only a player, but a major, positive player on the stage of international world politics. ${ }^{18}$ It may take a few decades for the dust to settle, but it will be interesting to read what future historians will have to say about the influence played by the religious faith of many of the members of the Solidarity movement and similar developments across Eastern Europe (as well as the role played by Pope John Paul II) in bringing about the dramatic political changes we saw unfold before us during the closing years of the twentieth century.

One essential element for authentic interreligious dialogue is a willingness on the part of all parties to examine uncomfortable issues. At times this may require a respectful expression of those points on which we differ, ones about which we must agree to disagree. At other times, these uncomfortable issues may be those that religious leaders must be willing to highlight, even if political leaders would rather we avoided them. For interreligious dialogue to have meaning and to be credible in the eyes of those whom we wish to influence, it must be free and not at the service of any one nation or any one political system. This dialogue must be at the service of all humanity.

16 Silvano Tomasi, "Holy See Address at U.N. on Religious Intolerance," speech delivered to the United Nations Human Rights Commission in Geneva (5 April 2004). Available at: www.zenit.org/english/visualizza.phtml?sid=51843.

17 Celestino Miglore, “Address to U.N. on Religion as a Value for Coexistence,” speech delivered to the United Nations General Assembly, New York (27 October 2004). Available at: www.zenit.org/english/visualizza.phtml?sid=61065.

18 Madeleine Albright, The Mighty and the Almighty: Reflections on America, God, and World Affairs (New York: Harper Collins Publishers, 2006). 
In a statement issued to world leaders on 8 September 2002 in anticipation of the first anniversary of the 9/11 attacks, Pope John Paul II noted that our efforts to respond to terrorism must "undertake new and creative political, diplomatic, and economic initiatives aimed at relieving the scandalous situations of gross injustice, oppression and marginalization which continue to oppress members of the human family."19 The Pope went on to point out that "the international community can no longer overlook the underlying causes that lead, young people especially, to despair of humanity, of life itself, of the future, and to fall prey to the temptations of violence, hatred and desire for revenge at any cost."

Earlier the same year, the Committee for Dialogue of the Pontifical Council for Interreligious Dialogue and the Permanent Committee of Al-Azhar for Dialogue with the Monotheistic Religions had noted that "dialogue alone is not sufficient to overcome extremism; there is always need for attention to basic aspects of society: family life, education, social development, the influence of the mass media; promotion of justice and solidarity within countries and on an international scale." ${ }^{20}$ In a statement issued in January 2006, Bishop Thomas Wenski, Chair of the United States' Conference of Catholic Bishops' Committee on International Policy, reiterated the Conference's belief that "terrorism cannot be fought solely, or even, principally, with military methods." ${ }^{21}$ One has only to look at how quickly Hezbollah began its humanitarian efforts in Lebanon after its recent conflict with Israel. Tip O’Neill, former congressman from Massachusetts and Speaker of the House of Representatives, is known for his famous quip, "all politics is local.” Maybe there is something to be learned in this example.

It might be helpful to reflect on a number of points as we consider ways to counter ideological support for terrorism. Some of these points will appear simplistic. They are. This is not to suggest that the issues are exactly the same across societies and religious groups. They are not. However, in recognizing that Islam is not monolithic, that it is not homogenous, and that there may be similarities at play that we may have never considered, we may begin to find ways to understand and speak with one another.

We know that some Muslims want to create a world society consistent with their religious beliefs, or at least with their particular interpretation of their religion. While we object to this desire and any consequent efforts on the part of anyone to impose a world view predicated on their own religious beliefs, we must recognize that the notion of creating a society, even a world-wide society, based on religious beliefs is not unique to any one religion.

Islam is rooted in the Koran, and the importance of scripture in the Muslim faith cannot be overemphasized. Muslims believe that the Koran is the word of God as communicated through the Prophet Muhammad. This belief is similar to that of some Christians who believe that the Bible is the literally true word of God. In American

19 Pope John Paul II, Address to New British Ambassador, Castel Gandolfo, Italy (8 September 2002). Available at: www.zenit.org/english/visualizza.phtml?sid=24830.

20 Vatican Press Office, "Interreligious Statement on Extremism.”

21 Thomas Wenski, “Toward a Responsible Transition in Iraq,” Washington, D.C. (12 January 2006). Available at: www.zenit.org/english/visualizza.phtml?sid=82689. 
history, many Christians pointed to the writings of St. Paul as a justification for the existence of slavery, and argued that scripture showed that it was indeed God's will that slaves be submissive to their masters. Paul's writings, among others, were also used as a justification for the subordinate role of women to men. Yet the U.S. Declaration of Independence proclaims that "all men are created equal" and are "endowed by their Creator with certain unalienable Rights...." One may think that that is simply the "old" American history, that we have moved beyond that. One has only to look at the current debate in the United States over the teaching of creationism, evolution, and/or the theory of "intelligent design" in public schools to realize that a literalist approach to sacred texts is not unique to any one religious group, culture, or nation. There are some Christian groups, in the United States and elsewhere, who wish to see current international and interreligious tensions intensify, especially in the Middle East, as they are convinced that this will help bring about Armageddon. Disputes about policy may often result from very strongly held differences of opinion among adherents of the same religion. Again, the notion of creating a society based on religious beliefs is not exclusive to any one religion. ${ }^{22}$

The importance of community (the Umma) in Islam cannot be overemphasized. People enter into a fellowship, and this communal bond is of primary importance. I am intrigued by the analysis offered by those who see potential problems in the social drift occurring in many democratic countries towards what is often called "secular humanism.” This form of secularism places primacy on the individual and individual rights. An important corollary to this view is the protection of those rights by the state. Some fear that the delicate balance and tension that exists, and that must always exist, between individual and communal rights are being subtly eroded.

The argument is made that secular humanism allows for-indeed, may actually facilitate - the breakdown of community. The individual is left in isolation before the state, divorced from other forms of community, for it is the relationship with the state, the protector and guarantor of individual rights, that takes precedence over other relationships. Indeed, rights may be viewed as arbitrary, to be given or taken as deemed expedient. (It is interesting to note that Dignitatis Humanae asserted religious freedom not as a "right," but as inherent in the dignity of the human person.) Such vulnerability allows for the enforcement of homogeneity, something that many ethnic, racial, and religious groups oppose for any number of reasons. Some have looked at these and similar developments as an indication of the anti-religious tendencies hidden in some understandings and expressions of secular humanism. ${ }^{23}$ In 2001, Archbishop Renato Martino, the Permanent Observer of the Holy See to the United Nations, had already expressed deep concerns about the findings of a report prepared by the Special Rap-

${ }^{22}$ Much has been written on the increasing role of religion in American political life. Kevin Phillips' American Theocracy (New York: Viking Press, 2006) is but one interesting analysis of this trend.

${ }^{23}$ For an interesting presentation of this view, see, among other works, Philip Jenkins' The New Anti-Catholicism: The Last Acceptable Prejudice (New York: Oxford University Press, 2003). 
porteur of the Commission on Human Rights. He discerned in the report that there was an "increase of extremism affecting all religions; and the gradual shift towards non-belief within society, characterized by a growing militancy that enters into competition or conflict with religions." ${ }^{24}$

In the United States, we are in the midst of what has been dubbed the "culture wars." If we look at some of the pivotal questions in these "wars," they often revolve around issues of religious faith and what social relationships and social structures "should" look like. Again, such discussions provide an example of a non-Muslim society that is largely based on religious beliefs. Questions about access to and the permissibility of abortion, issues concerning research using human stem cells, and gay marriage are just a few examples of the issues that evoke strong passions on all sides. In his address to the United Nations General Assembly in October 2004 cited earlier, Archbishop Celestino Miglore, the Holy See’s Permanent Observer to the United Nations, cautioned that "a greater exercise of individual freedoms may result in greater intolerance and greater legal constraints on the public expression of people's beliefs. The attitude of those who would like to confine religious expression to the merely private sphere ignores and denies the nature of authentic religious convictions. More often than not, what is being challenged, in effect, is the right of religious communities to participate in public, democratic debate in the way that other social forces are allowed to do.,25

While secular humanism may have much to recommend it, we must recognize that it is a powerful force that seeks hegemony by marginalizing and pushing to the side all other points of view. This tendency may indeed tend to increase frustration among those who object to secular humanism but who have few, if any, ways of escaping its increasing and ever more pervasive influence. It should be evident, therefore, that people for whom faith — and the ability to live and express that faith in community - is essential to their self-understanding will be reluctant to adopt a democratic government that is premised on secular humanism.

We know that there is and can be diversity within democratic approaches to government. For example, the First Amendment to the United States Constitution explicitly prohibits the establishment of an official or state religion. Thus, in the United States, the separation of church and state is considered an essential feature of our democratic form of government. In the United Kingdom, however, the Queen (who is also officially the head of state) is also head of the Church of England. While she has the right to appoint bishops in the Church of England, she does so in close consultation with her government's leaders. It is reasonable to assume that these leaders are not shy in advancing favorable opinions of those candidates whose theological outlook is consistent with and supportive of their party's economic, social, and political agenda. While the United Kingdom is a constitutional monarchy, most people would argue that

24 Renato Martino, “Holy See Statement on Religious Liberty,” address to the United Nations General Assembly, New York (13 November 2001). Available at: www.zenit.org/ english/visualizza.phtml?sid=12642.

25 Miglore, “Address to U.N. on Religion as a Value for Coexistence.” 
the British parliamentary system represents, and is consistent with, some of the oldest and most cherished principles of Western democratic government.

Democracies may do well to examine more closely, and more self-critically, the growing influence of secular humanism in their political, social, and economic thinking, and should perhaps begin to explore other avenues of thought-for example, intercultural humanism - that would allow and encourage their own further development as well as enable them to understand and promote democratic values within a variety of cultural contexts. Democratic nations might do well not to confuse a philosophical system with a political system. The former may be a way of buttressing the latter, but it need not be the only way. Conducting an examination of some of our own operative assumptions would be a good starting point in countering the ideological foundations of terrorism, and may help us in protecting our own democratic forms of government.

If we desire to convince others that democracy is indeed a better form of government than what others are offering, we must recognize the ways in which we, by our own actions, may be undermining our own efforts. In reflecting on some of the actions taken by the government of the United States in its efforts to gather information on terrorists' activities, earlier this year the United States' Conference of Catholic Bishops' Committee on International Policy stated that, "Our nation simply must live up to our own Constitution's prohibition against cruel and unusual punishment, and adhere to the Geneva Conventions of 1949 and the Convention against Torture and Other Cruel, Inhuman or Degrading Treatment or Punishment of 1984. As a world leader, our nation's adherence to international standards ought to be exemplary." ${ }^{26}$ There can be no substitute for the consistency and good example of all citizens in a democracy, regardless of their station, living under the rule of law if we hope to touch the hearts and minds of others.

This paper began with a brief overview of two documents issued by the Second Vatican Council, documents that represented a major shift in perspective for many in the Roman Catholic Church. The Church continues to struggle in trying to understand the implications of this invitation to a profound transformation of our own hearts and minds as we engage in dialogue with others from different faiths. In desiring to touch the hearts and minds of others in countering ideological support for terrorism, we must remain open to the possibility that our own hearts and minds may be touched as well.

26 Wenski, “Toward a Responsible Transition in Iraq.” 
WINTER 2006

\section{Bibliography}

Abbott, S.J. Walter. The Documents of Vatican II. New York: The America Press, 1966.

Albright, Madeleine. The Mighty and the Almighty: Reflections on America, God, and World Affairs. New York: Harper Collins Publishers, 2006.

Borelli, John. "Tracing the Contemporary Roots of Interreligious Dialogue." In Jesuit Interreligious Dialogue and Relations., 2005.

Jenkins, Philip. The New Anti-Catholicism: The Last Acceptable Prejudice. New York: Oxford University Press, 2003.

Wenski, Thomas. Toward a Responsible Transition in Iraq. Washington, D.C, 2006. 